\title{
TAGGING NARRATOR'S NAMES IN HADITH TEXT
}

\author{
N. A. Rahman ${ }^{1}$, N. K. Ismail ${ }^{1}$, Z. M. Nor ${ }^{2}$, M. N. $\operatorname{Alias}^{3}$, M. S. Kamis ${ }^{4}$ and N. Alias ${ }^{1, *}$ \\ ${ }^{1}$ Faculty of Computer and Mathematical Sciences, UniversitiTeknologi MARA, 40450 Shah \\ Alam, Selangor, Malaysia \\ ${ }^{2}$ Faculty of Quran danSunnah Studies, UniversitiSains Islam Malaysia, 71800 Nilai, Negeri \\ Sembilan, Malaysia \\ ${ }^{3}$ Faculty of Islamic Studies, UniversitiKebangsaan Malaysia, 43600 Bangi, Selangor, \\ Malaysia \\ ${ }^{4}$ PERMATApintar College, Universiti Kebangsaan Malaysia, 43600 Bangi, Selangor, \\ Malaysia
}

Published online: 17 October 2017

\begin{abstract}
Text document expresses enormous sort of information but it lacks the imposed structure of a traditional database. Unstructured data, particularly free running text data has to be transformed into a structured data. Extracting information from text is part of NLP process. The implementation of the NER algorithm for NLP is normally influenced by the domain of the studies. Besides, there is no existing system that is designed to detect the types of named entity in hadith text, develop POS tags and rule based extraction for narrator's name in Hadith Text in the Malay language. The POS tags were developed from 1000 hadith texts. The POS tags were created involving a total of 256 words which is part of narrator's names. The rule based was developed to determine five types of narrator's chain. Further research will determine the relationship between each narrator and the construction of narration's chain.
\end{abstract}

Keywords: tagging; hadith text; name.

Author Correspondence, e-mail: syahidah@uitm.edu.my

doi: http://dx.doi.org/10.4314/jfas.v9i5s.21 


\section{INTRODUCTION}

In [1] stated that Natural Language Processing (NLP) is an artificial intelligence branch which has the ultimate goal to invent theories, discover techniques and build software that can understand, analyze and generate the nature of human languages in order to interface with computers; both in written and spoken contexts using natural human languages, so NLP gives computers the ability to understand the way humans learn and use language and it is the most challenge inherent in natural language processing. The NLP techniques parse linguistic input (word, sentence, text, dialogue) according to the rules (derivational rules, inflectional rules, grammatical rules, etc.) and resources (like lexicon, corpus and dictionary) of the target language.

Text document expresses enormous sort of information. Unfortunately, it lacks the imposed structure of the traditional database. Therefore, unstructured data, particularly free running text data has to be transformed into a structured data [2]. The NLP research in texts which based other languages usually accepts the predetermined NLP. However, this has resulted in setbacks because the existing NLP needs to be suitable for other languages for its different structure and syntax [3-4].

The NLP research for Malay language has been carried out in the form of [5-7], stemming [8], part of speech tagging [5] and parsing [9-11]. However, there were some NLP tasks for Malay language which is yet to be explored in research such as the language recognition, stop word removal, word sense disambiguation. All the aforementioned are using the rule-based approach to execute the NLP task. In addition, the NLP research was implemented to analyze the sentence at various level of complexity. This research aimed for the Malay language, which is on Morphologic [8], Lexical [3,12], Syntactic [13-14] except for semantics.

Extracting information from text is part of NLP process [15]. However, there was no existing system that is designed to detect types of named entity in the Malay language until it is done by their group of research for the news article. The implementation of the NER algorithm for NLP is normally influenced by the domain of the studies [16]. Moreover, there was no existing system that is designed to detect types of named entity in hadith text. The Table 1 shows the study which was conducted by [17] that differs a number of domain and hadith that have been researched, NLP tools or approaches, classification algorithm were used along with 
the results produced. The number of hadith used is different between one another.

Table 1. Differentiating linguistic tools of approaches [17]

\begin{tabular}{|c|c|c|c|c|c|}
\hline Reference & \#Domains & \#Hadiths & $\begin{array}{c}\text { Linguistic } \\
\text { Tools/Approaches }\end{array}$ & $\begin{array}{c}\text { Classification } \\
\text { Algorithm }\end{array}$ & Results \\
\hline $\begin{array}{c}\text { Harrag et } \\
\text { al. } \\
(2008 ; 2009)\end{array}$ & 14 & 453 & $\begin{array}{l}\text { Stop-word } \\
\text { removal and } \\
\text { rule-based } \\
\text { morphological } \\
\text { stemming }\end{array}$ & $\begin{array}{l}\text { Decision trees, } \\
\text { Bayesian, } \\
\text { Entropy and } \\
\text { Vector space } \\
\text { models }\end{array}$ & $\begin{array}{c}\text { F1-measure }= \\
0.70 \text { with } \\
\text { decision trees }\end{array}$ \\
\hline $\begin{array}{l}\text { Harrag et } \\
\text { al. (2011) }\end{array}$ & & & $\begin{array}{l}\text { Three stemming } \\
\text { approaches; } \\
\text { rule-based; root } \\
\text { based and light } \\
\text { stemming }\end{array}$ & ANN vs. VSM & $\begin{array}{c}\text { F1-measure = } \\
0.5 \text { with ANN + } \\
\text { light or } \\
\text { rule-based } \\
\text { stemming }\end{array}$ \\
\hline $\begin{array}{l}\text { Alkhatib } \\
\text { (2010) }\end{array}$ & 8 & 1500 & $\begin{array}{l}\text { Removing chains } \\
\text { of narrators, stop } \\
\text { words and affixes }\end{array}$ & $\begin{array}{l}\text { Rocchio, } \\
\text { K-NN, Naive } \\
\text { Bayes and } \\
\text { SVM }\end{array}$ & $\begin{array}{c}\text { Recall }=100 \% \\
\text { Precision }= \\
63.36 \% \\
(\mathrm{SVM}) \text { and } \\
67.11 \% \\
\text { (Rocchio) }\end{array}$ \\
\hline $\begin{array}{l}\text { Al-Kabi } \\
\text { and }\end{array}$ & 12 & $\begin{array}{l}80 \text { (for } \\
\text { testing) }\end{array}$ & & $\begin{array}{l}\text { Vector Space } \\
\text { Models with }\end{array}$ & $\begin{array}{l}\text { F1-measure: } \\
\text { from } 0.42 \text { (Dice }\end{array}$ \\
\hline $\begin{array}{l}\text { Al-Sinjilawi } \\
\qquad(2007)\end{array}$ & & & & $\begin{array}{l}\text { several } \\
\text { similarity } \\
\text { measures }\end{array}$ & $\begin{array}{c}\text { Factor) to } 0.85 \\
\text { (Naïve } \\
\text { Bayesian) }\end{array}$ \\
\hline $\begin{array}{l}\text { Jbara } \\
(2010)\end{array}$ & 13 & 1321 & $\begin{array}{l}\text { Removing chains } \\
\text { of narrators, stop } \\
\text { words and affixes } \\
\text { Stem-based, Word }\end{array}$ & $\begin{array}{l}\text { The cosine } \\
\text { coefficient }\end{array}$ & $\begin{array}{l}49 \% \text { and } 37 \% \\
\text { of improvement } \\
\text { in F-measure } \\
\text { for hybrid }\end{array}$ \\
\hline
\end{tabular}




$\begin{gathered}\text { based and hybrid } \\ \text { representation }\end{gathered}$
compared to the
word-based and
the stem-based
methods

This paper focuses only on tagging the narrator's names in hadith texts, to extract the names in order to form the narrator's chain. The hadith texts that we use are in the Malay language. The structure of hadith text will be discussed in the next section.Section 2 is the discussion on the development of tagging and entity recognition process.Section 3 discusses the methodology used for hadith texts. Section 4 is the conclusion.

\section{RESULTS AND DISCUSSION}

A total of 1000 hadith texts were used as data in this process. In the first step, the raw of text document is split into narrator's chain and content by identifying the last narrator before Nabishallallahu 'alaihiwasallamorRasulullahshallallahu 'alaihiwasallam. This task is performed manually by hadith experts.

There are four types of narrator's chain part in hadith text as show in Table 2. The narrator's names were written in bold font.

Table 2. Types of narrator chain part in hadith text

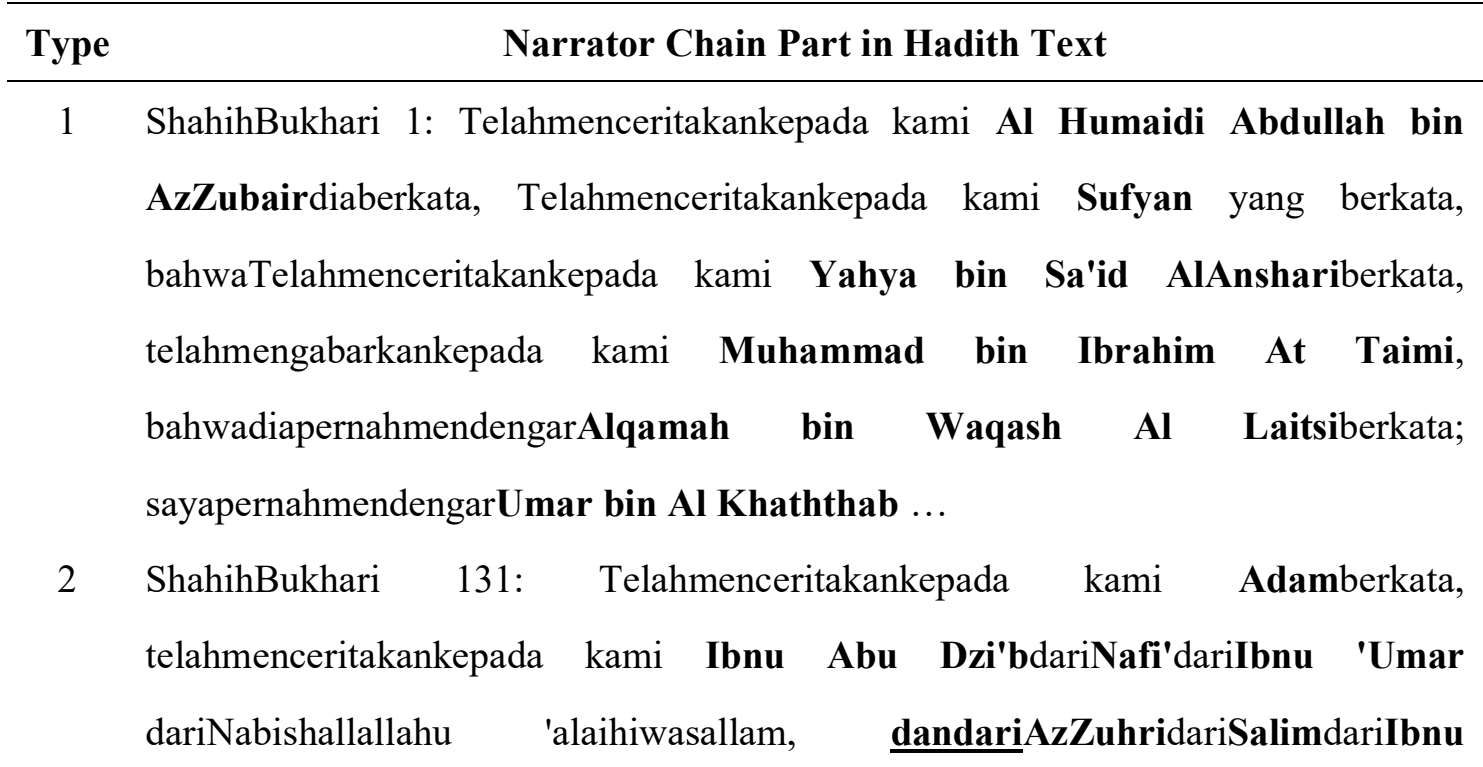


'UmardariNabishallallahu 'alaihiwasallam, bahwa ..

3 ShahihBukhari 134: Telahmenceritakankepada kami 'Aliberkata, telahmenceritakankepada kami Sufyanberkata, telahmenceritakankepada kami AzZuhridariSa'id bin Al Musayyab. (dalamjalur laindisebutkan) Telahmenceritakankepada kami 'Abbad bin TamimdariPamannya,...

4 ShahihBukhari 908: Dan (masihdarijalurperiwayatan yang samadenganhaditssebelumnya)dariJabir bin 'Abdullahiaberkata,

If the narrator's names extracted from the Type 1 hadith texts, it will produce the narrator's chain as shown in Fig. 6. Type 2 hadith texts will produce the narrator's chain as shown in Fig. 7. Type 3 hadith texts will produce two narrator's chains for one hadith text. The narrator's chain for Type 4 hadith texts is a continuation of the previous hadith text. For example the narrator's chain in hadith text number 908 is a continuation from hadith text number 907 . According to the domain expert, Type 2, 3 and 4 is featured by the underline sentence.

$\begin{array}{ll}\text { Abaidullah } & \text { Ady } \\ \text { Aban } & \text { Affan } \\ \text { Abas } & \text { Aflah } \\ \text { Abayah } & \text { Aghar } \\ \text { Abbad } & \text { Ahdab } \\ \text { Abbas } & \text { Ahmad } \\ \text { Abdah } & \text { Ahnaf } \\ \text { Abdan } & \text { Ahwal } \\ \text { Abdu } & \text { Ahwash } \\ \text { Abdul } & \text { Aidzullah } \\ \text { Abdullah } & \text { Aiman } \\ \text { Abdurrahim } & \text { Aisyah } \\ \text { Abdurrahman } & \text { Aizar } \\ \text { Abdurrazaq } & \text { Akwa } \\ \text { Abdurrazzaq } & \text { AL } \\ \text { Abdus } & \text { Al } \\ \text { Abdush } & \text { Ala } \\ \text { Abdushshamad } & \text { A'la } \\ \text { Abi } & \text { alaihi } \\ \text { Abidah } & \text { Allam } \\ \text { Abis } & \text { Alaqah } \\ \text { Abu } & \text { Ali } \\ \text { Abubakar } & \text { Aliyah } \\ \text { Abulshaq } & \text { Alqamah } \\ \text { Abu'mar } & \text { A'masy } \\ \text { AbuMusa } & \text { Amir } \\ \text { Abunadlr } & \text { Ammar } \\ \text { Abza } & \text { Amrah } \\ \text { Abzaa } & \text { Amru } \\ \text { Ad } & \text { An } \\ \text { Adam } & \text { AN } \\ \text { Adi } & \text { Anas } \\ \text { Adl } & \text { Anbasah } \\ \text { Adullah } & \text { Anshari } \\ & \end{array}$

Aqadi
Ar
Arab
A'raj
Ar'arah
Arat
Arim
Arqam
Arubah
As
Asad
Asadi
Ash
Ashbagh
Ashbahani
Ashim
Aslam
Aslami
Asma
Assa'idi
Aswad
Asy
Asy'ari
Asy'ats
Asykari
Asyyab
At
Ath
Atha
Athiyah
Athiyyah
Atho
Atho'
Ats

Auf
Aun
Auza'i
Awanah
Awaqi
Awza'i
Ayyasy
Ayyub
Az
Azdi
Azib
Aziz
Badal
Bakali
Bakar
Bakr
Bakrah
Banani
Bani
Bara
Barirah
Barro
Barzah
Basyar
Basyir
Basysyar
Bathin
Bazi
Bilal
bin
binti
Bisyir
Bisyr
Buhainah

Bukair
Bunani
Bundar
Buraid
Buraidah
Burdah
Busr
Busyair
Darawardi
Darda
Dastawa'I
Daud
Dimsyqi
Dinar
Ditsar
Dlamrah
Dlamri
Dluba'i
Dluha
Dukain
Dzakwan
Dzar
Dzarr
Dzarri
Dzi'b
Fadlal
Fadlalah
Fadll
Fadlol
Faqir
Faraj
Farqad
Farsi
Fatimah

Fazari
Fudaik
Fudlail
Fulaih
Ghailan
Ghalib
Gharair
Ghasil
Ghassan
Ghifari
Ghiyats
Ghundar
Habasyi
Habhab
Habib
Habibah
Had
Haddad
Hadi
Hadrad
Hadza
Hadzdza
Hafsh
Hafshah
Haiwah
Hajjaj
Hakam
Hakim
Halhalah
Hamam
Hamid
Hammad
Hammam
Hamzah

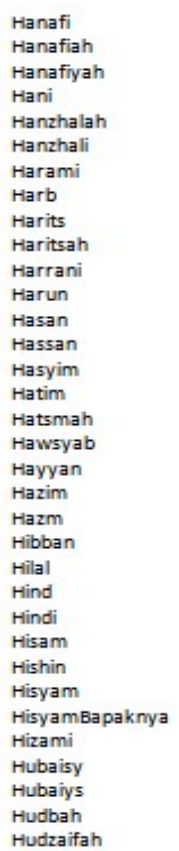

Fig.1.Tagging narrator's name

The second step, we use regular expressions in Python statement number 1 is to tokenize the narrator's chain part into words. For further explanation please refer to [15]. However, before we apply the regular expressions; we remove "“"” and "_" symbols that were used widely in 
Malay hadith text to improve the POS tagging process. After the tokenization process, we remove the words consist of only "'" symbol to improve the entity recognition process.

From the tags that we developed, it produces 671 words. For example Al Humaidi Abdullah bin AzZubair will be separated into 6 words which are Al,Humaidi, Abdullah, bin, AzandZubairas shown in Fig. 1, 2 and 3. Fig. 4 shows narrators using relationship and additional information as a name.

\begin{tabular}{|c|c|c|c|c|c|c|}
\hline Hudzifah & Jabal & Khair & Makhramah & Miswar & Muqaddam & Namir \\
\hline Humaid & Jabar & Khaldah & Makki & Mu'adz & Muqaddami & Nashir \\
\hline Humaidi & Jabir & Khali & Malih & Mu'adzah & Muqatil & Nashr \\
\hline Humran & JabirSamurah & Khalid & Malik & Mu'afa & Mugotil & Nauf \\
\hline Hunain & Ja'd & Khallad & Ma'n & Mu'alla & Musa & Nu'aim \\
\hline Hurairah & Ja'di & Kharrabudz & M'an & Mu'allaa & Musadad & Numair \\
\hline Husain & Jami & Khaulani & Manshur & Mu'awiyah & Musattab & Qais \\
\hline Hushain & Jamrah & Khaza'i & Maqbari & Mu'awiyyah & Musayyab & Qalabah \\
\hline Husyaim & Jarir & Khiyar & Maqburi & Mubarak & Mush'ab & Qa'nab \\
\hline Huwairits & Jazari & Khubaib & Ma'rur & Mudlar & Mushir & Qa'qa \\
\hline Huwirits & Jirasy & Khudri & Marwan & Mudrik & Muslim & Qari \\
\hline Ibrahin & Juhaim & Laila & Mas'ud & Muhabbar & Mu'tamir & Qawariri \\
\hline Idris & Juhaini & Lailatul & Masyruq & Muhajir & Muthahhar & Qaza'ah \\
\hline Ikrimah & Juhani & Laits & Mathar & Muhammad & Muthalib & Qilabah \\
\hline Ima'il & Junda'i & Laitsi & Mawali & Muhammadar & Mutharrif & Qotadah \\
\hline Imran & Jundub & Ma'an & Mazani & Muharib & Muth'im & Qudamah \\
\hline Irak & Juraij & Ma'bad & Mazini & Muharibi & Muththalib & Qurasyi \\
\hline Isa & Jurairi & Madini & Mihran & Mujahid & Mutsanna & Qurrah \\
\hline Ishaq & Juwairiah & Mahak & Mihshan & Mujmir & Muzani & Qutaibah \\
\hline Iskandarani & Juwairiyah & Mahbub & Mijlaz & Mukhtar & Muzni & Rabbi \\
\hline Isma'il & Juwairiyyah & Mahdi & Mikhwal & Mulaikah & Nabi & Rabbih \\
\hline Israil & $\mathrm{Ka} \mathrm{a}^{\mathrm{b}}$ & Mahmud & Minhal & Munabbih & Nadlar & Rabdzah \\
\hline
\end{tabular}

Fig.2. Tagging narrator's name

And then, the rules based were developed to assign the tags to the narrator's chain part in the hadith text. Next, the narrator's names recognition process using the Python statement number 2 in Table 3 to identify the names.

Statement 2 in Table 3 is the patterns of narrator's chain exist in hadith text, as shown in Table 2. But, the narrator's name itself also has many patterns as shown in Table 4. 


\begin{tabular}{|c|c|c|c|c|c|}
\hline Raja & Shafiyah & Sya'bi & Tsaqafi & Wadlih & Zaid \\
\hline Rasulullah & Shafiyyah & syadad & Tsaur & Wahab & Zaidah \\
\hline Rasyid & Shafwan & Syaddad & Tsauri & Wahb & Zai'dah \\
\hline Rauh & shalih & Syadzan & Tsumamah & Wahhab & Za'idah \\
\hline Rawwad & shallallahu & Syaibah & Tumailah & Wahid & Zainab \\
\hline Rib'i & shalt & Syaiban & Ubadah & Wahsyiyyah & Zakaria \\
\hline Rifa'ah & Shaltu & Syaibani & Ubaid & Wail & Zanad \\
\hline Sa'ad & shamad & syaqiq & Ubaidah & Wa'il & Zaraqi \\
\hline Sa'd & Shamit & syarik & Ubaidillah & Waki & Zayadi \\
\hline Safar & Sha'Sha'ah & Sya'unah & Ubaidullah & Walid & Zinad \\
\hline Sahal & Sha'sha'ah & syidad & Ubay & Waqash & Zina dbarmwa \\
\hline Sahl & shiddiiq & syihab & Ufair & Waqid & Ziyad \\
\hline sa'ib & Shiddiq & Syu'ah & Ulayyah & WaqidMuhammad & Ziyadi \\
\hline Said & Shubaih & Syu'aib & Umair & Warits & Zubaid \\
\hline Sa'id & Shuhaib & Syu'bah & Umais & Warqa & Zubaidi \\
\hline Sa'idi & shurad & Syuhab & Umamah & Warrad & Zubair \\
\hline Saif & simak & Syumail & Umar & wasallam & Zubairi \\
\hline Sa'in & siman & Syuraih & Umarah & Washil & Zuhair \\
\hline Sakhtiyani & Sinan & Taghlib & Umayyah & Washithi & Zuhri \\
\hline Salam & Sirin & Taim & Ummu & Wasi & Zuhrii \\
\hline Salamah & Siyah & Taimi & Uqail & Wasithi & Zuhry \\
\hline Salami & sufyan & Taimillah & Uqbah & Wuhaib & Zur'ah \\
\hline Salim & Suhail & Tamim & Urwah & Wuhhaib & Zurai \\
\hline Salman & Sukain & Tamimah & Urwahl & Yaar & Zuraqi \\
\hline Sam & Sulaim & Tayyah & Usamah & Ya'fur & Zurarah \\
\hline Saman & Sulaiman & Thahman & Usmah & Yahya & \\
\hline Samrah & sumayya & Thalhah & Utbah & Ya'la & \\
\hline Sarah & sumayyah & Thalib & Utsman & Yaman & \\
\hline Sayyar & Suqah & Thariq & Uwais & Ya'qub & \\
\hline Sayyarah & Suraij & Thawil & Uwaisi & Yasar & \\
\hline shabah & Suramari & Thawus & Unvaisy & Yasir & \\
\hline Shabbah & surwaid & Thufail & Uyainah & Yazid & \\
\hline Shadaqah & Suyan & Tiyah & Wadi'ah & Yunus & \\
\hline Shafar & Syababah & Tsabit & Wadldlah & Yusuf & \\
\hline
\end{tabular}

Fig.3. Tagging narrator's name

$\begin{array}{ll}\text { Relationship } & \text { Additional information } \\ \text { bapakku } & \text { nama } \\ \text { Bapaknya } & \text { aslinya } \\ \text { Bapakku } & \text { adalah } \\ \text { Pamannya } & \text { dia } \\ \text { pamannya } & \text { yakni } \\ \text { bapaknya } & \text { adalah } \\ \text { lbunya } & \text { yaitu } \\ \text { Kakeknya } & \text { Yaitu } \\ \text { Anak } & \text { namanya } \\ \text { anak } & \text { mantan } \\ \text { saudara } & \text { budak } \\ \text { bibiku } & \text { puteri } \\ \text { anak } & \text { isteri } \\ \text { ayahnya } & \text { kakek } \\ \text { saudaranya } & \text { anak } \\ \text { Saudaranya } & \text { saudara } \\ \text { Saudaraku } & \text { Bani } \\ & \text { bani } \\ & \text { Haritsah } \\ & \text { Nabi } \\ & \text { lbu } \\ & \text { kaum } \\ & \text { Ummul } \\ & \text { Mu'minin } \\ & \text { Mukminin } \\ & \text { Muk'minin } \\ & \text { Mantan } \\ & \text { sahaya } \\ & \text { anaknya } \\ & \\ & \\ & \end{array}$

Fig.4. The name using relationship and additional information 
Table 3.Python statements

\begin{tabular}{|c|c|}
\hline No & Python Statements \\
\hline 1 & perPerkataan $=$ re.findall $\left(\mathrm{r}^{\prime \prime}\left|\mathrm{W}+\left(?:\left[-{ }^{-}\right] \mid \mathrm{w}^{+}\right)^{*}\right|^{\prime} \mid\left[-.(]+|| \mathrm{S} \backslash \mathrm{w}{ }^{*}\right.\right.$, , hadis $)$ \\
\hline \multirow[t]{7}{*}{2} & grammer = r"'"' \\
\hline & POPeriwayatan: \\
\hline & $\{<\mathrm{NPW}>+<\mathrm{PADD}>*<\mathrm{NPW}>+\}$ \\
\hline & $\{<\mathrm{NPRW}>*\}$ \\
\hline & $\{<$ DUA $><$ DUA $>\}$ \\
\hline & $\{<$ PECAHAN $><$ PECAHAN $>\}$ \\
\hline & $\{<$ SAME $><$ SAME $>\}$ \\
\hline
\end{tabular}

Table 4.Narrator's name pattern

\begin{tabular}{ll}
\hline Narrator's Name Pattern in Hadith & \multicolumn{1}{c}{ Explanation } \\
\hline Al Humaidi Abdullah bin AzZubair & Al Humaidi Abdullah: Name of narrator \\
& bin: son of \\
& AzZubair: Name of father's narrator \\
& Mean his/her uncles of previous narrator \\
Pamannya & Sa'id: Name of narrator \\
Sa'iddiaadalahanaknya Abu Sa'id & diaadalahanaknya: son of \\
& Abu Sa'id: Name of father's narrator \\
& 'Amru: Name of narrator \\
& yaitu: is \\
& IbnuMaimun: Name of narrator \\
\hline
\end{tabular}

Sentence "diaadalahanaknya" means the son of and "yaitu" means is/are the additional information, which narrator used to differentiate between narrators that have the same name but different person. Fig. 5 shows hadith text after the POS tags were applied and the name entity extraction process.

\section{Input 1:}

ShahihBukhari 8: Telahmenceritakankepada kami Abdullah bin Muhammad Al Ju'fidiaberkata, Telahmenceritakankepada kami Abu 'Amir Al 'Aqadi yang berkata, 
bahwaTelahmenceritakankepada kami Sulaiman bin Bilal dari Abdullah bin Dinar dari Abu Shalihdari Abu Hurairah ...

\section{Output 1:}

\begin{tabular}{l}
\hline POS-taggingNamaPeriwayatan-Notepad \\
File Edit Format View Help \\
\hline Abdullah NPW bin NPW Muhammad NPW Al NPW Ju'fi NPW \\
Abu NPW Amir NPW Al NPW Aqadi NPW \\
Sulaiman NPW bin NPW Bilal NPW \\
Abdullah NPW bin NPW Dinar NPW \\
Abu NPW Shalih NPW \\
Abu NPW Hurairah NPW \\
\hline
\end{tabular}

\section{Input 2:}

ShahihBukhari 101: Telahmenceritakankepada kami 'Abdullah bin Yusuf berkata,, telahmenceritakankepadasaya

Syuraihbahwadiaberkatakepada 'Amru bin Sa'id ...

\section{Output 2:}

\begin{tabular}{|l|}
\hline POS-taggingNamaPeriwayatan - Notepad \\
File Edit Format View Help \\
\hline Abdullah NPW bin NPW Yusuf NPW \\
Al NPW Laits NPW \\
Sa'id NPW dia PADD adalah PADD anaknya PADD Abu NPW Sa'id NPW \\
Abu NPW Syuraih NPW \\
Amru NPW bin NPW Sa'id NPW \\
\\
\end{tabular}

\section{Input 3:}

ShahihBukhari 134: Telahmenceritakankepada kami 'Ali berkata, telahmenceritakankepada kami Sufyanberkata, telahmenceritakankepada kami AzZuhridariSa'id bin Al Musayyab. (dalamjalur lain disebutkan) Telahmenceritakankepada kami 'Abbad bin TamimdariPamannya ..

\section{Output 3:}

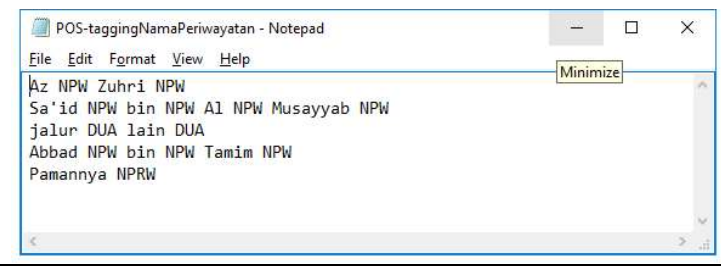

Fig.5.After POS tags and name entity extraction process

\section{EXPERIMENTAL}


This section will highlight on hadith text structure and the development design for tagging narrator's name in hadith text and extract them. Hadith text structures consist of sanaddanmatn [18] as shown in Fig. 6.
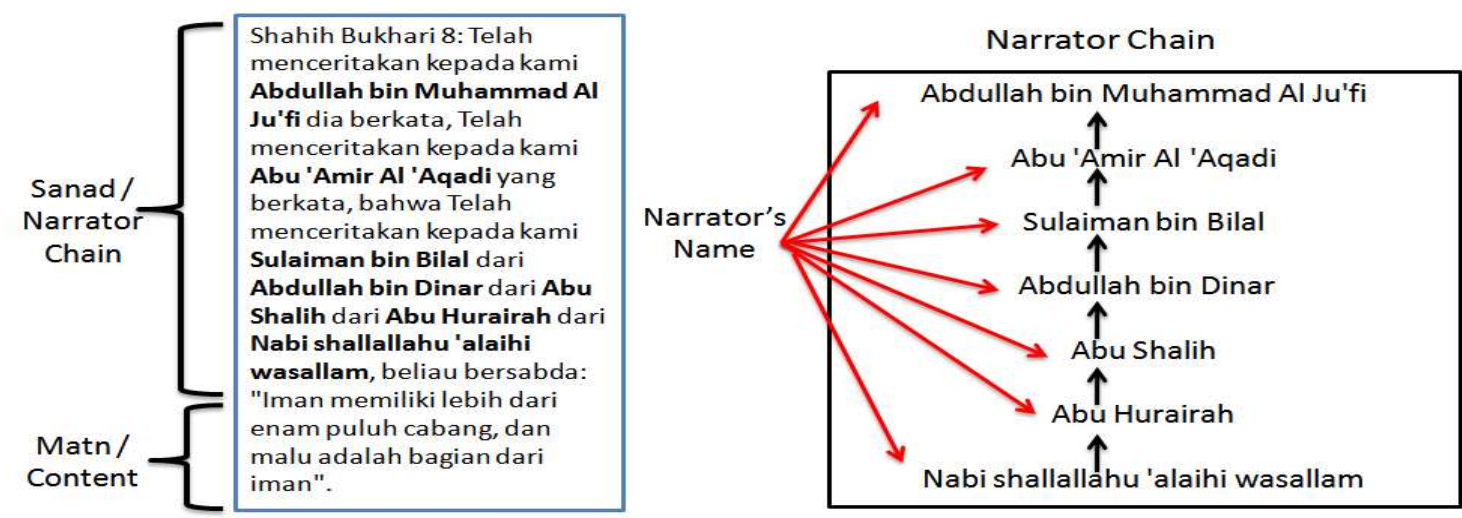

Fig.6.Hadith text in Malay text document

The figure shows the hadith text in ShahihBukhari book number 8, taken from [19]. The database that became the reference in the field of hadith research, education and public utilisation. Each Hadith is composed of two important component: the actual narrative text, known as Content/Matn and the chronological list of people who were the transmitters of the Content/Matn, also known as Narrator's Chain/Isnad [20-22]. Sanad/Narrator's Chain part in Fig. 6 is "Telahmenceritakankepada kami Abdullah bin Muhammad Al Ju'fidiaberkata, Telahmenceritakankepada kami Abu 'Amir Al 'Aqadi yang berkata, bahwaTelahmenceritakankepada kami Sulaiman bin Bilal dari Abdullah bin Dinar dari Abu Shalihdari Abu HurairahdariNabishallallahu 'alaihiwasallam, beliaubersabda:". Therefore, the narrator's chain existed in the aforementioned hadith were "Nabishallallahu 'alaihiwasallam $\rightarrow$ Abu Hurairah $\rightarrow$ Abu Shalih $\rightarrow$ Abdullah bin Dinar $\rightarrow$ Sulaiman bin Bilal $\rightarrow$ Abu 'Amir Al 'Aqadi $\rightarrow$ Abdullah bin Muhammad Al Ju'fi'. Meanwhile, the content for the hadith in Fig. 6 is for the statement "Imanmemilikilebihdarienampuluhcabang, danmaluadalahbagiandariiman". The separation between the content and the narrator's chain in the diagram below are clear and marked with the symbol ":".

Fig. 7 shows that the hadith text has two narrator's chain in one hadith text. The first narrator's chain in the hadith is "Rasulullahshallallahu 'alaihiwasallam $\rightarrow$ Ibnu 'Abbas $\rightarrow$ Ubaidullah bin Abdullah $\rightarrow$ AzZuhri $\rightarrow$ Yunus $\rightarrow$ Abdullah $\rightarrow$ Abdan". The second narrator's 
chain is "Rasulullahshallallahu 'alaihiwasallam $\rightarrow$ Ibnu 'Abbas $\rightarrow$ Ubaidullah bin Abdullah $\rightarrow$ AzZuhri $\rightarrow$ YunusdanMa'mar $\rightarrow$ Abdullah $\rightarrow$ Bisyir bin Muhammad'. Meanwhile, the hadith content is "Rasulullahshallallahu 'alaihiwasallamadalahmanusia yang paling lembutterutamapadabulanRamadlanketikamalaikatJibril 'Alaihis Salam menemuinya, danadalahJibril 'Alaihis Salam mendatanginyasetiapmalam di bulanRamadlan, dimanaJibril 'Alaihis Salam mengajarkan Al Qur'an. SungguhRasulullahshallallahu 'alaihiwasallamjauhlebihlembutdaripadaangin yang berhembus". The separation between content and narrator's chain in the hadith was ambiguous and it has been referred to the hadith researchers.

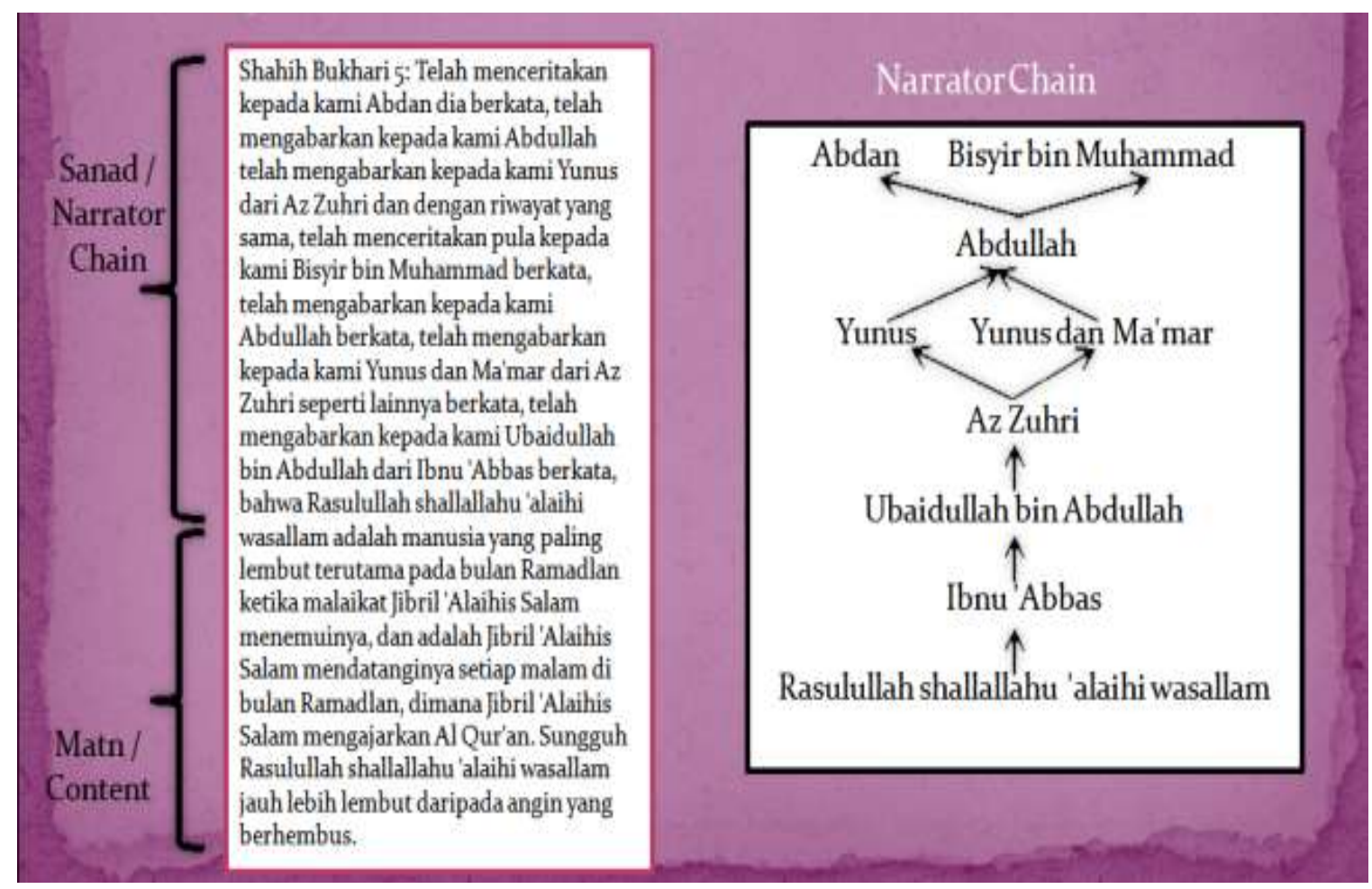

Fig.7.Hadith text with two narrator chain in Malay text document

Next, Fig. 8 shows the architecture for a simple information extraction system [15] that we referred to. First, the raw of the text document is split into narrator's chain and content by identifying the last narrator before Nabishallallahu 'alaihiwasallamorRasulullahshallallahu 'alaihiwasallam. This process is conducted with domain expert who is an academician in Islamic Study specific in Hadith study. We processed only the narrator's chain part. The narrator's chain is further subdivided into words using tokenizer. 


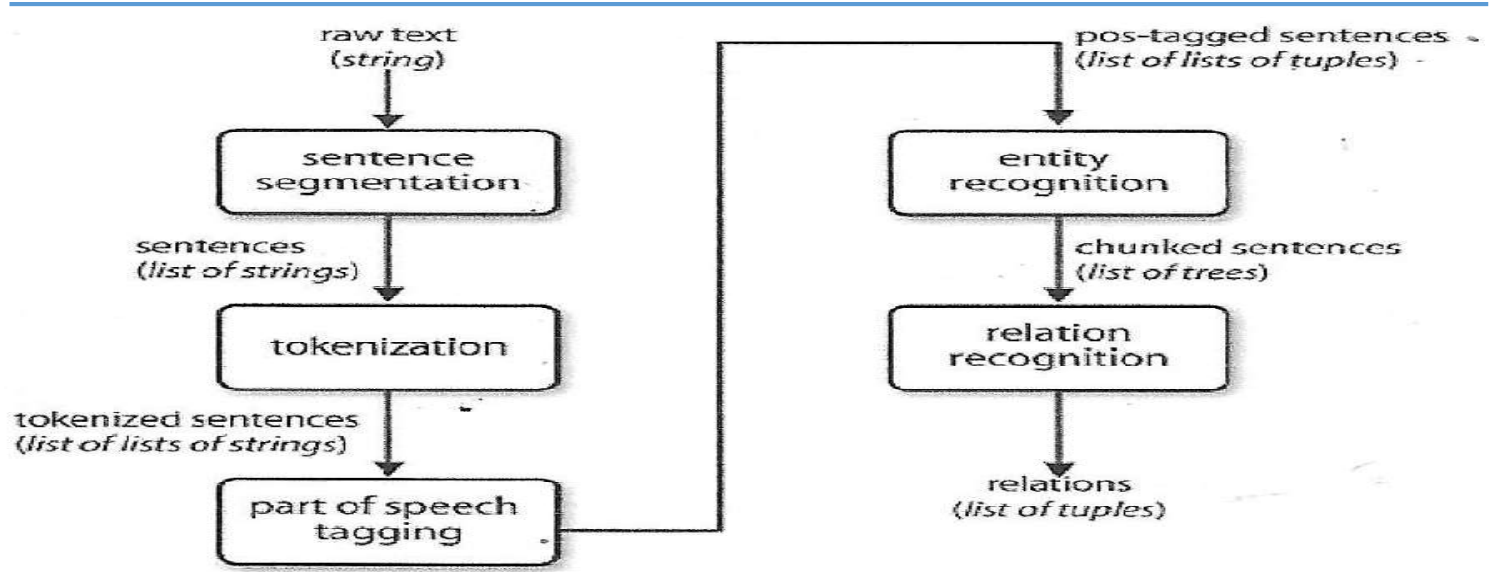

Fig.8. Simple information extraction architecture [15]

Then, the narrator's chain part is tagged with part-of-speech (POS) tags, which will prove to be helpful in the next step, narrator's name entity recognition. Due tothere are no existing POS tags for narrator's name in hadith text, we developed the POS tags. We also refer to a rule based Malay NER framework proposed by [16] to develop a rule based on identifying types of named entity in the Malay language for hadith text. For the final step, we reserved it for future research. The rule based was developed by using Python Programming language $[23,15]$

\section{CONCLUSION}

This research developed POS tags and rule based extractions for narrator's name in Hadith Text in the Malay language. The POS tags were developed from 1000 hadith texts. The POS tags were created involving a total of 256 words which were part of narrator's names. The rule based was developed to determine five types of narrator's chain. Further research will determine the relationship between each narrator and the construction of narration's chain.

\section{ACKNOWLEDGEMENTS}

This research was funded by the Malaysian Government under Fundamental Research Grant Scheme (FRGS) (FRGS/1/2015/ICT01/UITM/03/1) in UniversitiTeknologi MARA, Shah Alam. 


\section{REFERENCES}

[1] Najeeb M M, Abdelkader A A, Al-Zghoul M B. Arabic natural language processing laboratory serving Islamic sciences. International Journal of Advanced Computer Science and Applications, 2014, 5(3):114-117

[2] Harish B S, Guru D S, Manjunath S. Representation and classification of text documents: A brief review. IJCA Special Issue on Recent Trends in Image Processing and Pattern Recognition, 2010, 110-119

[3] Hong J L. MalayWordNet-A novel lexical database for Malay language.In 10th International Conference on Fuzzy Systems and Knowledge Discovery, 2013, pp. 773-777

[4] Ab Rahman S, Omar N, Ab Aziz M J. A fundamental study on detecting head modifier noun phrases in Malay sentence.In International Conference on Semantic Technology and Information Retrieval, 2011, pp. 255-259

[5] Alfred R, Leong L C, On C K, Anthony P. Malay named entity recognition based on rule-based approach. International Journal of Machine Learning and Computing, 2014, 4(3):300-306

[6] Nazri M Z A, Shamsudin S M, Bakar A A. An exploratory study of the Malay text processing tools in ontology learning. In 8th International Conference on Intelligent Systems Design and Applications, 2013, pp. 1-8

[7] Ranaivo M B. Building a rule-based Malay text segmentation tool. In International Conference on Asian Language Processing, 2011,pp. 276-279

[8] Lee J, Othman R M, Mohamad N Z. Syllable-based Malay word stemmer. In IEEE Symposium on Computers and Informatics Syllable-based, 2013, pp. 7-11

[9] Mohamed H H, Abu B Z, Ismail M. Evaluation of Malay grammar on translation of Al-Quran sentences using Earley algorithm. In 5th International Conference on Information and Communication Technology for the Muslim World, 2013, pp. 1-4

[10] Ab Rahman S, Omar N, Che Hassan N B. Construction of compound nouns (CNs) for noun phrase in Malay sentence. In International Conference on Information Retrieval and Knowledge Management, 2012, pp. 22-25

[11] Yaman M B. MyParser: A Malay text categorization toolkit using inference rule. Master thesis, Johor: Universiti Tun Hussein Onn Malaysia, 2013 
[12] Don Z M. Processing natural Malay texts: A data-driven approach. Trames, 2010, 14(1):90-103

[13] Kasbon R, Amran N A, Mazlan E M, Mahamad S. Malay language sentence checker. World Applied Sciences Journal, 2011, 12(Special Issue on Computer Applications and Knowledge Management):19-25

[14] Basri S B, Alfred R, On C K. Automatic spell checker for Malay blog. In IEEE International Conference on Control System, Computing and Engineering, 2013, pp. 506-510 [15] Bird S., Klein E., Loper E. Natural language processing with python: Analyzing text with the natural language toolkit. California: O’Reilly Media Inc, 2009

[16] Alfred R, Leong L C, On C K, Anthony P, Fun T S, Razali M N, Hijazi M H A.A rule-based named-entity recognition for Malay articles.In International Conference on Advanced Data Mining and Applications, 2013, pp. 288-299

[17] Faidi K, Ayed R, Bounhas I, Elayeb B. Comparing Arabic NLP tools for hadith classification. International Journal on Islamic Applications in Computer Science And Technology, 2015, 3(3):1-12

[18] Zaraket F, Makhlouta J. Arabic cross-document NLP for the hadith and biography literature. Procein 25th International Florida Artificial Intelligence Research Society Conference Arabic, 2013, pp. 256-261

[19] LidwaPusaka. Ensiklopediahaditskitab 9 imam. Jakarta Timur: LidwaPusaka andSaltanera, 2010

[20]Azmi A M, Badia N bin. e-Narrator-An application for creating an ontology of hadiths narration tree semantically and graphically. Arabian Journal for Science and Engineering, 2010, 35(2):51-68

[21] Al-MunajjidM S. Conditions of a Sahih (sound) hadith. Riyadh: Islamic Propagation Office in Rabwah, 2009

[22] Aldhaln K, Zeki A, Zeki A, Alreshidi H. improving knowledge extraction of hadith classifier using decision tree algorithm. In International Conference on Information Retrieval and Knowledge Management, 2012, pp. 148-152

[23] Zed A. S.Learn python the hard way: A very simple introduction to the terrifyingly beautiful world of computers and code. Boston: Addison-Wesley, 2014 
How to cite this article:

Rahman N A, Ismail N K, Nor Z M, Alias M N, Kamis M S, Alias N. Tagging narrator's names in hadith text. J. Fundam. Appl. Sci., 2017, 9(5S), 295-309. 